\title{
PERSPECTIVES ON RESTRICTING THE EXERCISE OF CONSTITUTIONAL RIGHTS AND FREEDOMS IN ORDER TO ENSURE NATIONAL SECURITY
}

DOI: 10.47743/rdc-2019-2-0003

Ioan Dumitru APACHITEI ${ }^{1}$

\section{Abstract}

The current study aims at presenting the conditions under which the restriction of the exercise of constitutional rights and freedoms can operate in order to satisfy the measures regarding the protection of national security. One the one hand, the valences of constitutional law of this topic lie on the fact that the adopted measures must be in close correspondence with the exigencies of the Constitution, and on the other hand, the checking of the conditions of adopting specific measures to restrict constitutional rights and freedoms is the prerogative of the Constitutional Court asked to verify the compliance with the provisions of the Fundamental Law.

Keywords: control of constitutionality; proportionality principle; sovereignty; national security

\section{General perspectives}

Rights and freedoms are a foundation of the rule of law and the interdependence between the citizens and the state. This aspect is also revealed by placing the constitutional provisions regarding rights and freedoms in the second part of the fundamental law, thus enunciating their primary role. The matter of fundamental rights and freedoms enshrined in the Constitution has a strong reference in international agreements in this matter, regarding this, the provisions of Article 20 of the fundamental law are relevant, it enshrines the prevalence of the Universal Declaration of Human Rights ${ }^{2}$, as well as other international pacts and treaties to which Romania

${ }^{1}$ PhD student, Faculty of Law of "Alexandru Ioan Cuza” University of Iaşi, lawyer at the Iaşi Bar, e-mail: ioandumitruapachitei@gmail.com.

2 The Universal Declaration of Human Rights was adopted by the General Assembly of the United Nations on December $10^{\text {th }}, 1948$. Following the adoption of the declaration, it was also stated by the former US Secretary of State, Henry Kissinger, that there is an incompatibility between the protection of human rights and national security, highlighting the economic and geopolitical interests of the United States; in this regard, see also W. Burke-White, Human Rights and National Security: The Strategic Correlation, in Harvard Human Rights Journal, Vol. 17/2004, p. 251. 
has acceded, except in the case where the Constitution contains more favorable provisions $^{3}$.

The limitation of rights and freedoms is not only a perspective of the Romanian constitutional legislator, such limitations are also the subject of international acts. In accordance to Article 4 of the International Covenant on Civil and Political Rights ${ }^{4}$, the clauses derogating from the obligations assumed by the states regarding the civil and political rights and freedoms have been established, in essence, the limitation being conditioned by the existence of situations of strict necessity and non-discrimination. However, the second paragraph of the article we are referring to states that no derogation from a number of rights is allowed, including the right to life, protection against torture and slavery, freedom of conscience and the principle of the lawfulness of criminal offenses and punishments and non-retroactivity of criminal law.

The provisions of Article 15 of the ECHR ${ }^{5}$ are applying the same reasoning, these allow states to derogate from the provisions of the Convention in situations of war or public danger threatening the life of the nation, provided that there is compliance with the necessity of the adopted measure. Such action shall be accompanied by an obligation of notifying the General Secretary of the European Council, in regards to the adopted measure, as well as the reasons and the date on when it ceases, thus marking the exceptional and temporary nature of the restriction of rights and freedoms proclaimed by the Convention. Complementarily, the provisions of Article 18 of ECHR stipulate that the limitation of rights must occur only for the strictly provided purposes.

Moreover, the Charter of Fundamental Rights of the European Union ${ }^{6}$ regulates exceptional situations from which restrictions on the rights and freedoms of citizens of the Member States of the European Union may arise. In this regard, we refer to the provisions of Article 52 para. 1 of the Charter that provide for the possibility of restricting the rights enshrined in the Charter, however, the limits of the restriction are also established as being represented by the provision of the law, the restriction to be occurring in regards to the substance of the rights and freedoms guaranteed by the Charter and to respect the proportionality and necessity of the measure in relation to

${ }^{3}$ In this regard, also see C. Ionescu, Treaty of contemporary constitutional law, $3^{\text {rd }}$ ed., C.H. Beck Publishing House, Bucharest, 2019, p. 891.

4 The act was adopted by the United Nations General Assembly on December $16^{\text {th }}, 1966$ and entered into force on March 23 ${ }^{\text {rd }}$, 1976. Ratification by Romania was affected by Decree no. 212 of October 31 $1^{\text {st }}, 1974$ and was published in the Official Gazette of Romania no. 146 of November 20 1974.

5 The act was drafted by the Council of Europe and signed on November $4^{\text {th }}, 1950$ and entered into force on September $3^{\text {rd }}$, 1953. Romania ratified its accession to the ECHR by Law no. 30/1994, published in the Official Gazette of Romania no. 135 on May 31st, 1994.

${ }^{6}$ Drafted in 2000, the Charter of Fundamental Rights of the European Union gained legal force through the Treaty of Lisbon. Thus, Article 6 of the Lisbon Treaty provides in para. 1 that "the Union recognizes the rights, freedoms and principles set out in the Charter of Fundamental Rights of the European Union of December $7^{\text {th }}, 2000$, as it was adapted on December 12th 2007 , in Strasbourg, which has the same legal value as the Treaties".

\section{CONSTITUTIONAL LAW REVIEW}




\section{Perspectives on restricting the exercise of constitutional rights and freedoms...}

the situation in which it is to be adopted ${ }^{7}$. Finally, the restrictions imposed must meet "the general objectives of interest set by the Union or the need to protect the rights and freedoms of others".

It is appreciated that national security is a given of the state sovereignty, an element that includes all the measures meant to ensure the maintenance of the sovereignty, unity, independence and indivisibility of the state ${ }^{8}$. In the specialized literature, a lato sensu perspective of the idea of national security was also approached as representing a state towards which the state tends through the application of measures and approaches ${ }^{9}$. On the same stage of maintaining national security, it was also stated that the restriction of the exercise of human rights and freedoms is justified and more important the factors that threaten national security, even more restrictions may increase ${ }^{10}$.

An element of distinction regarding the modification of the provisions of Article 53 of the Romanian Constitution ${ }^{11}$ is the replacement of the concept of "national safety" with "national security". The change in the constitutional provision is substantial and concerns gender-to-species reporting, in the sense that national security also includes national safety ${ }^{12}$.

On the other hand, national security is defined by the Romanian legislator in Article 1 of Law no. 51/1991 $1^{13}$ as "the state of legality, balance and social, economic and political stability necessary for the existence and development of the Romanian national state as a sovereign, unitary, independent and indivisible state, maintaining the rule of law, as well as the climate of unrestricted exercise of the fundamental rights, freedoms and duties of the citizens, according to the democratic principles and norms established by the Constitution". We should notice that the legislator approaches a causal link between national security and protection of the Romanian State and its citizens, in this regard making a parallel between the provisions of Article 1 para. 1 of the Romanian Constitution and the need to respect constitutional rights and freedoms ${ }^{14}$.

\footnotetext{
${ }^{7}$ In this regard, see also para. 31 of The decision of Constitutional Court no. 198 of March 23rd, 2017, published in the Official Gazette of Romania no. 515 of July $4^{\text {th }}, 2017$.

${ }^{8}$ I. Busuioc, The relationship between national security and national security, Journal of Public Security Studies, Vol. I, no. 4/2012, p. 30.

${ }^{9}$ See G. Velicu, Law and legislation on national defense insurance, Publishing House of South, Craiova, 1999, p. 42.

${ }^{10}$ See W. Burke-White, op. cit., p. 253.

11 See also the jurisprudence indicated in T. Toader, M. Safta, Romanian Constitution, $3^{\text {rd }}$ ed., Hamangiu Publishing House, 2019. It should also be mentioned that prior to the revision of the Constitution in 2003, the indicated provisions correspond to the provisions of Article 49 of the Romanian Constitution of 1991.

12 I. Busuioc, op. cit., p. 30. See also M.A. Chiorean, National Security of Romania in the context of world geopolitical changes, Primus Publishing House, Oradea, 2012, p. 44, the quoted author subsumes to the notion of national security both national safety and national defense, respectively the public order. In the same regard, see also S. Frolu, Judicial Security in the paradigm of national security, in Dreptul no. 1/2017, p. 159, with the mention that this author retains as content elements of national security national defense, national safety and the rule of law.

${ }^{13}$ Republished based on Article 107 para. 3 of Law no. 255/2013 and published in the Official Gazette of Romania no. 190 of March $18^{\text {th }}, 2014$.

${ }^{14}$ See also G. Velicu, op. cit., pp. 129-132.
} 
The approach of the national security was also the object of the Decision of the Constitutional Court of Romania, which in relation to the proposal to revise the provisions of Article 119 para. 2 and 3 noted that "national security is achieved within the democratic order by fully exercising civil rights and freedoms, consciously assuming responsibilities, improving the decision-making and action capacity of the state, as well as affirming Romania as an active member of the international community. As a national instrument that gives strength and concrete value to these requirements, the national security strategy is an integrative factor of synthesis, which is materialized through a set of decisions, plans, measures and actions designed to effectively prevent and counteract the risks and threats endangering national values and interests, as well as the values that give identity and unity to European construction"15. It should be noted that the notion of national security has acquired a broad meaning that includes a multitude of interests in interdependence with the objectives of the state and the degree of social evolution, an aspect to which the Constitutional Court Decision to which I referred earlier states that it is subsumed under national security "internal security, energy security, food security, transport and infrastructure security, public health security, financial security, computer security etc.". Far from being an exhaustive list, the Court seeks to outline the limits of the notions that can be included in the concept of national security ${ }^{16}$.

In a similar approach, in accordance to the Decision no. 802 of December $5^{\text {th }}$, $2018^{17}$, the Romanian Constitutional Court established in para. 62 and 63 that "the achievement of national security is achieved by knowing, preventing and removing internal or external threats that may affect the values provided in Article 1 of the same normative act. Thus, the achievement of national security is not a future projection, but is an ongoing process that maintains the existing state of national security. The complex of activities carried out by state bodies with responsibilities in the field of national security is limited to this sphere and aims at obtaining information to ensure the knowledge, prevention and removal of internal or external threats to national security. On the other hand, criminal activity is intended to establish the existence or non-existence of a crime, to identify the person that committed it, to know the circumstances that contribute to finding out the truth in criminal proceedings, necessary for the fair settlement of the case, with the aim at prosecuting the guilty person. Thus, the purpose for which the activities undertaken in the field of national security are used is different from that of criminal proceedings. The first focus on the knowledge, prevention and removal of internal or external threats in order to achieve national security and the others aim at prosecuting those who have committed crimes (...)".

\footnotetext{
${ }^{15}$ Decision of Romanian Constitutional Court no. 799 of June $17^{\text {th }}, 2011$, published in the Official Gazette of Romania no. 440 of June $23^{\text {rd }}, 2011$.

${ }^{16}$ See also Decision of Romanian Constitutional Court no. 872 of June $25^{\text {th }}, 2010$, published in the Official Gazette of Romania no. 433 of June $28^{\text {th }}, 2010$.

${ }^{17}$ Decision published in the Official Gazette of Romania no. 218 of March 20"th 2019.
} 


\section{Perspectives on restricting the exercise of constitutional rights and freedoms...}

\section{National security as an argument for restricting fundamental rights}

\section{and freedoms}

\subsection{The need to restrict fundamental rights and freedoms}

There is an apparent conflict of interest between the desire of uniform respect for constitutional rights and freedoms and measures to restrict those rights. We mentioned that it is only an apparent conflict, because, in essence, there is the problem of a conflict of individual and general values. From the theory of the social contract, elaborated by the philosopher Jean-Jacques Rousseau, we can establish a hierarchy of social values. The social contract implies the cession of "natural freedom" in order to acquire the advantages determined by belonging to the social framework, therefore also the assumption of responsibility towards the social rules, and their violation attracts the subject's responsibility towards the social contract. In other words, the restriction of the exercise of fundamental rights and freedoms comes as a counterweight to the social interest.

An important distinction is also made between the restriction and the derogation from the exercise of fundamental rights. The difference is a quantitative one, following to report to the notion of restriction to the extent that it concerns hypotheses regulated by law which intervene in order to defend a social interest. On the other hand, the derogation from fundamental rights and freedoms is broader in the sense that they are more intrusive in the privacy of individuals. However, the two concepts have a number of similarities regarding the non-discrimination condition, the temporary and exceptional nature of the measure ${ }^{18}$.

The issue of restriction of fundamental rights is treated at national level in the light of the provisions of Article 53 of the Romanian Constitution that refer to the limits of the competence of the Parliament in adopting a measure in this regard. The extent to which the legislator appreciates the opportunity and intensity of the restriction of constitutional rights is assessed by the Constitutional Court, the institution competent to analyse the conformity of a law in the matter with the provisions of Article 53 of the Fundamental Law ${ }^{19}$. In this context, the Constitutional Court has a strong role in what the literature calls "the constitutionalisation of law", in other words, the updating of lower legal norms in accordance with the provisions of the Fundamental Law ${ }^{20}$.

${ }^{18}$ See D.C. Mâță, National Security. Concept. Regulation. Means of protection, Hamangiu Publishing House, 2016, p. 104.

${ }^{19}$ C. Ionescu, C.A. Dumitrescu (coord.), Romanian Constitution. Comments and explanations, C.H. Beck Publishing House, Bucharest, 2017, p. 626.

${ }^{20}$ See T. Toader, M. Safta, Constitutional Litigation Course, Hamangiu Publishing House, Bucharest, 2017, p. 61 . 


\subsection{The conditions of the restriction of certain fundamental rights or freedoms}

Analysing the provisions of Article 53 of the Constitution, it can be noted that the legislator provided a series of conditions regarding the permissiveness of restricting the exercise of certain rights or freedoms. Thus, the establishment of such restrictions can be achieved by law, in the cases strictly provided for by Article 53 para. (1) and in compliance with the conditions of necessity, proportionality, non-discrimination and temporality ${ }^{21}$.

Among the causes that may justify the restriction of the exercise of constitutional rights, the defense of national security is expressly provided. Given the fact that this is the only element that is the subject of this study, we will limit only to dealing with this matter. The rest of the conditions listed above are directly applicable.

The restriction may operate only with regard to the exercise of the constitutional rights, provided in Title II of the Fundamental Law, implicitly excluding the other subjective rights ${ }^{22}$, and the restriction must be understood in terms of the limitation of rights or freedoms, which does not prevent the limitation of the right itself, so it is only a matter of restricting the exercise of rights and freedoms, and not of their substance ${ }^{23}$. In this sense, we should mention the Decision of the Romanian Constitutional Court no. 318 of September $14^{\text {th }}, 2004^{24}$, where the author of the exception of unconstitutionality complained that the lifting of the debtor's right to conduct his activity as a result of the establishment of the procedure of judicial reorganization and bankruptcy, regulated by Law no. 64/1995 ${ }^{25}$, represents an infringement of the substance of the right to private property, as it is regulated by Article 136 para. 5 of the Romanian Constitution. With regard to the exception invoked, the Court held, on the one hand, that the trader's right to coordinate the activity does not fall within the

${ }^{21}$ In the same sense, see also para. 51 of the Decision of the Constitutional Court of Romania no. 244/2017, published in the Official Gazette of Romania no. 529 of July $6^{\text {th }}, 2017$.

22 In this regard, see para. 3 and 14 of Decision of the Constitutional Court of Romania no. 666 of October $24^{\text {th }}, 2017$, published in the Official Gazette of Romania no. 72 of January $25^{\text {th }}, 2018$. In essence, the Court notes that "the right to drive on public roads cannot be confused with the right to free movement, a fundamental right enshrined in art. 25 of the Constitution (...) nor the suspension of the exercise of the right to drive, for a period of 60 days, according to the criticized text of law, cannot be included in the normative hypothesis of art. 53 of the Constitution, which envisages the restriction of the exercise of a constitutional right or freedoms".

${ }^{23}$ See D.C. Mâță, op. cit., p. 104; E.S. Tănăsescu in I. Muraru, E.S. Tănăsescu (coord.), Romanian Constitution. Commentary on articles, C.H. Beck Publishing House, Bucharest, 2008, p. 533. In the same sense, see the Decision of the Constitutional Court of Romania no. 1414 of November 4th, 2009, published in the Official Gazette of Romania no. 796 of November 23th 2009 , where the Court held that "the sole purpose of the right's exercise is to avoid the imminent risk of economic instability of the country, and the limitation concerns the exercise of the right, not its substance. According to the jurisprudence of the Constitutional Court, economic stability is subsumed under the concept of national security, the constitutional basis for limiting certain rights enshrined in the Fundamental Law".

${ }^{24}$ The decision was pronounced on September $14^{\text {th }}, 2004$, and published in the Official Gazette of Romania no. 992 of October $28^{\text {th }}, 2004$.

${ }^{25}$ Law no. 64/1995 was repealed by Law no. 85/2006. Currently the headquarters of the matter is regulated by Law no. 85/2014, published in the Official Gazette of Romania no. 466 of June 25 2014.

\section{CONSTITUTIONAL LAW REVIEW}




\section{Perspectives on restricting the exercise of constitutional rights and freedoms...}

matter of fundamental rights and freedoms provided in the Article 53 of the Romanian Constitution, and on the other hand, this measure has the effect of making the goods unavailable, without affecting the debtor's own property right.

The provisions of Article 53 para. 1 of the Romanian Constitution expressly regulates the fact that the restriction of the exercise of certain rights or freedoms can be achieved "only by law". In this regard, the notion of law can be understood either in a narrow sense or in a broader sense. Under this last landmark, the meaning of the notion of law, viewed lato sensu, can integrate several normative acts. However, it is necessary to take into account the fact that the constituent legislator established an imperative condition, given the fact that it aims to restrict the exercise of certain rights or freedoms, namely an intrusive measure. Therefore, the notion of law must be understood stricto sensu, as representing only the laws issued by the Parliament, an aspect that should exclude the ordinances issued by the Government ${ }^{26}$. In the sense of those specified, we take into account para. 15 of the Decision of the Constitutional Court of Romania no. 666 of October $24^{\text {th }}, 2017^{27}$, which establishes that "contrary to the claims of the exception's author, emergency ordinances may regulate even in the reserved area, according to Article 73 para. 3 of the Romanian Constitution, the organic law, with strict observance of the imperative and limiting conditions established in Article 115 para. 4-6 of the Fundamental Law. Therefore, even from this perspective, the alleged violation of Article 53 nor of Article 73 para. 1 of the Constitution can not be taken into consideration", so that it can be observed that a narrow meaning of the notion of law is approached, emphasizing that by emergency ordinances it can be regulated in the field of organic law, therefore also regarding the fundamental rights and freedoms to which it refers Article 115 para. 6 of the Romanian Constitution, but without affecting them ${ }^{28}$,

${ }^{26}$ Also see C. Ionescu, op. cit., pp. 894-895. The quoted author also offers a contrary example by Government Ordinance no. 50/1994 on the establishment of a border crossing tax in order to establish resources for social protection and notes that "the Law on the repeal of this ordinance was declared unconstitutional by the Decision of the Constitutional Court no. 139 of December 14 ${ }^{\text {th }}, 1994^{\prime \prime}$. From the content of the mentioned decision it is noted that the Romanian Constitutional Court establishes as a matter of principle the necessity and proportionality of the restrictive measures, thus, "in the absence of specifying the right in favor of whom the restriction takes place, from the simple reference to social protection rights (Art. 1 of the ordinance) or to the social assistance rights (Art. 7 of the ordinance), it does not result either that this restriction "is imposed" - as provided by Art. 49 para. 1 of the Constitution - nor that it is proportional to the situation that determined it as it provides para. 2 of the same article".

27 The decision was published in the Official Gazette of Romania no. 72 of January $25^{\text {th }}, 2018$.

${ }^{28}$ Regarding the notion of injury to which it refers Art. 115 para. 6 of the Romanian Constitution, the Decision no. 1189 of November $6^{\text {th }}, 2008$, of the Constitutional Court, published in the Official Gazette of Romania no. 787 of November $25^{\text {th }}, 2008$, states that "it can be deduced that the prohibition on the adoption of emergency ordinances is total and unconditional when it states that 'they cannot be adopted in the field of constitutional laws' 'and that' 'they cannot target measures of forced passage of public property'. In the other areas covered by the text, ordinances of emergency can not be adopted if 'affect' and if they have negative consequences, but, instead, they can be adopted if, through the regulations they contain, they have positive consequences in the areas in which they intervene". Further more, the Court noted that the meaning of the verb "to affect" is the equivalent to that of "suppress", "harm" or "injure".

STUDIES AND ARTICLES 
so without being able to restrict their exercise ${ }^{29}$. In a recent opinion ${ }^{30}$ it was shown that the phrase "only by law" must be understood by corroborating the provisions of Article 53 with the provisions of Article 115 para. 6 of the Romanian Constitution, in the sense that the constitutional provisions exclude only emergency ordinances from the scope of normative acts by which the exercise of fundamental rights and freedoms may be restricted, implicitly, admitting the possibility to operate such restrictions through simple ordinances, regulating in the field of ordinary law.

Although the regulation on constitutional rights and freedoms is materialized by the law issued by the Parliament or by the normative acts initiated or issued by the Government, the legislative power is not the only authority involved in this process. Thus, in order for the Government to promote such a normative act, it is necessary to have requested the approval of the Supreme Council of National Defense ${ }^{31}$, which in turn determines whether a particular situation poses a threat to national security ${ }^{32}$.

The exceptional situations that may justify the restriction of the exercise of fundamental rights and freedoms derive from the provisions of Article 53 para. 1 of the Romanian Constitution, the provision referring to the fact that measures can be taken "only if necessary". This aspect concerns the principle of necessity, such a measure must be necessary, a ultima ratio that the legislator can use.

Another principle necessary to meet the constitutionality conditions in order to restrict fundamental rights and freedoms is the principle of proportionality. This mandatory condition constitutes a fair balance between the gravity of the social danger that determines taking a measure in the indicated sense. At the same time, it represents the landmark of the legislator in establishing the intensity that the measure will have on the recipients of the norm, thus avoiding an excess of legislative power ${ }^{33}$. However, the analysis of the proportionality test also involves an analysis of constitutionality, in which case the Court is called upon to decide the extent to which a restriction on the exercise of fundamental rights and freedoms is considered proportionate and such an analysis

\footnotetext{
${ }^{29}$ Also see E.S. Tănăsescu in I. Muraru, E.S. Tănăsescu (eds.), op. cit., p. 536. The quoted author claims that the delegated legislator cannot intervene by emergency ordinance on fundamental rights and freedoms, including both the regulation, modification and restriction of their exercise.

${ }^{30}$ C.-L. Popescu, Restriction of the exercise of fundamental rights and freedoms by decrees establishing or prolonging the state of emergency or siege and by military ordinances, available at https://drept.unibuc.ro/ dyn_img/aubd/Restrangerea\%20exerci\%C8\%9Biului\%20drepturilor.pdf, accessed on April 22nd, 2020.

${ }^{31}$ In this matter, the Romanian Constitutional Court has developed a rich jurisprudence, in the sense that we refer to Decision no. 507 of September 18 ${ }^{\text {th }}$, 2019, published in the Official Gazette of Romania no. 864 of October $25^{\text {th }}, 2019$ and Decision no. 17 of January 21st 2015 , published in the Official Gazette of Romania no. 79 of January 30, 2015;

32 The cases that represent threats to national security are provided in the provisions of Art. 3 of Law no. $51 / 1991$, with the limitations provided by Art. 4 of the same normative act. In this respect, it is worth mentioning that by the Romanian Constitutional Court's Decision no. 802 of December $5^{\text {th }}, 2018$, para. 73, it is stated that the "notion of 'national security' is inextricably linked to the elements provided by Art. 3 of Law no. 51/1991, the scope of this notion being also determined by them".

${ }^{33}$ Also see C. Ionescu, op. cit., p. 905.
} 


\section{Perspectives on restricting the exercise of constitutional rights and freedoms...}

may lead to a readjustment of the intrusion's degree ${ }^{34}$. The principle of proportionality also means that the restriction of the exercise of fundamental rights or freedoms is the only possible measure, so that if there are other means capable of being applied but which do not involve such restrictions, they must be applied as a matter of priority ${ }^{35}$.

Regarding the principle of proportionality, we find that by Romanian Constitutional Court's Decision no. 139 of December $14^{\text {th }}, 1994^{36}$, the Court ruled that "this proportionality can only be established in consideration of a certain right for the realization of which, as provided in para. 1 of the same article, the restriction is required'. In other words, the restriction of a constitutional right - in this case, the right to free movement provided in Article 25 of the Constitution - in order to defend the rights of citizens it is possible, according to Article 49 of the Constitution, only in consideration of a certain right, as a necessary measure, since, without this restriction, that right would be seriously affected and, according to the principle of proportionality, only within the limits necessary for that right not to be, at least in part, compromise. In fact, in this situation, a right is affected by law to safeguard another right, the importance of which the legislator considers paramount. However, in the absence of specifying the right in favor of which the restriction takes place, the mere reference to social protection rights (Article 1 of the ordinance) or to social assistance rights (Article 7 of the ordinance) does not show that this restriction 'is necessary-as provided in para. 1 in Article 49 of the Constitution - nor that it is proportional to the situation that determined it - as provided by para. 2 of the same article".

The limitation in time of fundamental rights and freedoms' restriction is given precisely by the exceptional situations which require such measures and, therefore, the measures adopted in this regard must be strictly limited in relation to their need. The temporary character is necessarily correlated with the very limitation of the substance of rights or freedoms, and not with the limitation of the right itself. A deviation from this aspect could lead to the justification of a measure whose applicability is not final, which suggests, however, even the denial of the effects of the rights and freedoms provided in the Constitution.

A final condition concerns the non-discriminatory nature of the restrictions. It is considered that under this aspect, the provisions of Article 53 must be corroborated with the ones of Article 4 and Article 16 para. 1 of the Romanian Constitution. The latter provisions enshrine the principle of solidarity of citizens and non-discrimination, as well

\footnotetext{
${ }^{34}$ See M.-M. Pivniceru, K. Benke, Receiving the principle of proportionality in the jurisprudence of the Constitutional Court of Romania. German constitutional influences, in the Journal of Constitutional Law no. $1 / 2015$, p. 60.

35 See E.S. Tănăsescu in I. Muraru, E.S. Tănăsescu (coord.), op. cit., p. 543.

36 The decision was published in the Official Gazette of Romania no. 353 of December 21st, 1994. Look for Constitutional Court of Romania's Decision no. 375 of July $6^{\text {th }}, 2005$, published in the Official Gazette of Romania no. 591 of July $8^{\text {th }}, 2005$, respectively Constitutional Court of Romania's Decision no. 872 of June $25^{\text {th }}$, 2010, published in the Official Gazette of Romania no. 433 of June $28^{\text {th }}, 2010$.
}

STUDIES AND ARTICLES 
as equality of citizens before the law and public authorities ${ }^{37}$. It was also pointed out that the constitutional judge cannot decide on the application of the rule that is covered by the exception of unconstitutionality, so that if the rule meets the conditions of constitutionality, the Court will reject the exception, so there is no ruling on the principle of non-discrimination ${ }^{38}$.

\section{Reporting to the jurisprudence of the ECHR and the CJEU on the restriction of fundamental rights and freedoms}

In the jurisprudence of the Constitutional Court, we often find references to the jurisprudence of the ECHR or the CJUE. The decisions of the Constitutional Court on the jurisprudence of the European courts is based on the fact that Romania is a party to the ECHR and the European Union. With regard to the jurisprudence of the ECHR, it is found that there are regulated a number of rights from which states may derogate, and others where either the regulation of contrary provisions is prohibited or they are largely restricted. The literature also referred to the rights that may be derogated from by classifying them into general derogations and specific derogations ${ }^{39}$, the difference being that general derogations have been established by case law and specific derogations have not been the subject of a case before the Court yet.

The restriction of the exercise of constitutional rights and freedoms can intervene only within the limits in which the measures are provided by law and are necessary, conditions corresponding to Article 53 para. 2 of the Romanian Constitution and Article 8 of the ECHR. ECtHR's reference is the case Lambert v. France, where the ECtHR determines that there may be an interference with private life, but is necessary to fulfil the requirements and provisions in law of the necessary measures to achieve the purpose ${ }^{40}$. ECtHR also ruled on the provision by law of the restriction of fundamental rights in the case of Rotaru v. Romania" ${ }^{41}$, para. 52, stating that the notion of "provision in law" must be understood in conjunction with its accessibility and predictability to the recipients of the rule ${ }^{42}$. In the same sense, the Court also ruled in the case of lordachi

37 See C. Ionescu, op. cit., p. 905.

${ }^{38}$ See E.S. Tănăsescu in I. Muraru, E.S. Tănăsescu (coord.), op. cit., p. 546.

${ }^{39}$ See S. Peers, National Security and European Law, in Yearbook of European Law, Oxford, Vol. 16, no. 1/1996, pp. 394-395.

${ }^{40}$ With regard to ECtHR, decision of August 24th 1998 , the case of Lambert v. France; also see para. 48 of Romanian Constitutional Court's Decision no. 802/2018, published in the Official Gazette of Romania no. 218 of March 20 ${ }^{\text {th }}, 2019$, respectively para. 50-52 of Romanian Constitutional Court's Decision no. 244/2017, published in the Official Gazette of Romania no. 529 of July 6 $6^{\text {th }}, 2017$.

41 The case was published in the Official Gazette of Romania no. 19 of January $11^{\text {th }}, 2001$.

${ }^{42}$ Also see C. Bîrsan, European Convention on Human Rights. Comment on articles. Vol. I. Rights and freedoms, All Beck Publishing House, Bucharest, 2005, pp. 665, 675 and 676.

\section{CONSTITUTIONAL LAW REVIEW}




\section{Perspectives on restricting the exercise of constitutional rights and freedoms...}

and others $v$. Moldova ${ }^{43}$, stating that the establishment of a measure restricting rights must be the subject of a rule compatible with the provisions of national law and, in addition, accessible to the parties, so that they can foresee the consequences of acts contrary to legal provisions.

Compliance with the conditions for the restriction of the rights and freedoms' exercise also refers to the necessity to specify the period during which the restrictive measures would be applicable, as well as the possibility of verifying the legality of the restrictions imposed. As a reference to this is the decision of the CJEU in the case of Yassin Abdullah Kadi and the Al Barakaat International Foundation v. Council of the European Union and Commission of the European Communities of September $3^{\text {rd }}$, $2008^{44}$. In essence, the appellants were against Council Regulation (EC) no. 881/2008 of May $27^{\text {th }}, 2002^{45}$ on the imposition of restrictive measures against persons and entities allegedly linked to Osama bin Laden and the Al-Qaeda network, which are included in Annex I to the Regulation and, consequently, suffer certain justified restrictions on the right to property, justified on putting on risk the national security. Because their case was dismissed by the General Court ${ }^{46}$, was challenged in ECtHR. The Grand Chamber established in para. 370-376 that the inclusion of the appellants in the regulation's annex entails the imposition of considerable restrictive measures on the right to property and judicial protection, which would justify the person having access to an examination by the competent authorities, as correlated with the provisions of Article 1 of Protocol no. 1 to the $\mathrm{ECHR}^{47}$. It has been shown that the lack of the right to an examination as well as the unpredictability of the duration of the restrictive measure is an unjustified excess. The Court also established that the contested regulation must be annulled, in so far as it concerns the appellants, however, it established on the basis of Article 231 of the EC Treaty that the effects of this act may be maintained for a maximum period of 3 months, within which the Council must remedy the contested act ${ }^{48}$.

${ }^{43}$ ECtHR, decision of February 10 th 2009 , Iordachi and others v. Moldova, para. 37.

${ }^{44}$ The judgment was the subject of related cases C-402/05 P and C-415/05 P.

${ }^{45}$ The regulation had as purpose the implementation of Resolution no. 1267 of October $15^{\text {th }}, 1999$ of the UN Security Council, on the seizure of funds belonging to persons and entities suspected of links with terrorist organizations.

${ }^{46}$ The case was rejected by decision of September $21^{\text {st }}, 2005$, Case T-315/01.

${ }^{47} \mathrm{ECtHr}$, decision of January $5^{\text {th }}, 2000$, case Beleyer v. Italy.

${ }^{48}$ Also see A. Tomkins, National Security and the Due Process of Law, in Current Legal Problems from University College London, Faculty of Laws, vol. 64, no. 1/2011, p. 221.

STUDIES AND ARTICLES 
4. Rights and freedoms whose restriction cannot be justified on grounds

\section{of national security}

Even though national security may justify the restriction of the exercise of certain fundamental rights or freedoms, however, there can be identified a number of such rights and freedoms from which it cannot be derogated from, as it was illustrated by the way the constitutional legislator expresses himself and the case law of the Constitutional Court and ECHR's. From a terminological point of view, it should be noted that the rights and freedoms to which we refer are not subjects to restriction in terms of their exercise, since such a restriction is similar to the very suppression of the substance of the right or freedom.

The freedoms regarding thought, conscience and religion are provided by the provisions of Article 29 of the Romanian Constitution, respectively Article 9 of the ECHR. The Constitution expressly refers to the fact that such freedoms "cannot be restricted in any way" and the Convention gives a similar perspective, even stating that they are necessary for the national security. In the case of Nolan and K. v. Russia ${ }^{49}$ the applicant, missionary of the Unification Church, was banned from entering Russia, due to the fact that its missionary activities would constitute a threat to national security. The Court decided that the Russian Government had not proved the nature of the applicant's activities which might have interfered with national security, and consequently it was shown that observance of religious freedom was a primary right, and no restrictions on national security were permitted, Article 9 of the ECHR being a restrictive one.

The right to life is regulated by the constitutional legislator through the provisions of Article 22 para. 2 and 3 of the Constitution. According to Article 2 of the ECHR, it is established that this right is guaranteed. The stated provisions must be understood in the light of Protocol no. 6 and 13 to the ECHR, which states the abolition of the death penalty and the prohibition of possible derogations on the grounds of national security.

The prohibition of torture, degrading or inhuman treatment is regulated by the provisions of Article 22 para. 2 of the Romanian Constitution, respectively Article 3 of the ECHR. The Strasbourg Court has a consistent jurisprudence on the irreconcilability between the violation of the provisions of Article 3 and national security. In this perspective, it also ruled in the case of Chahal v. The United Kingdom ${ }^{50}$, where it was decided that the applicant's expulsion justified by the threat to national security must

${ }^{49}$ ECtHR, the decision of February 12 $2^{\text {th }}, 2009$, case Nolan and K. v. Russia, para. 73.

${ }^{50} \mathrm{ECtHR}$, the decision of November $15^{\text {th }}, 1996$, the case of Chahal v. United Kingdom, para. 75 to 77. In the same vein, see also ECtHR, the decision of December 14 Court recalls that Article 3 of the Convention enshrines one of the fundamental values of democratic societies. Even in the most difficult circumstances, such as the fight against terrorism and organized crime, the Convention prohibits in absolute terms torture and inhuman or degrading treatment or punishment. Article 3 does not provide for restrictions, in contrast to most of the normative clauses of Convention and Protocols no. 1 and 4 and according to Article $15 \S 2$ does not suffer any derogation, even in case of public danger that threatens the life of the nation". 


\section{Perspectives on restricting the exercise of constitutional rights and freedoms...}

take into account the possibility that he might be subject to a risk of degrading or inhuman treatment in the country of destination ${ }^{51}$. The Court considered that to the extent of such a risk, the expulsion of the person is contrary to the provisions of Article 3 of the Convention and it would not be justified regardless of the nature and gravity of the person's activities ${ }^{52}$. The same reasoning was adopted by the Court in the case of El Masri v. Former Yugoslav Republic of Macedonia ${ }^{53}$, where it was noted that in examining the danger of being subjected to degrading or inhuman treatment or torture, no account should be taken of matters relating to the national security of the State from which the expulsion is sought.

\section{Conclusions}

The importance of protecting fundamental rights and freedoms is a comprehensive approach, guaranteed by the rigorous establishment of situations in which their restrictions may be imposed.

The revision of the Constitution in 2003 sought, among others, a better clarification of the hypotheses of restriction of constitutional rights and freedoms, the replacement of the "national safety" notion with that of "national security" being understood in regard to the extension of the hypotheses that may be incidental. The jurisprudence of the Constitutional Court has also consistently facilitated the understanding, interpretation and establishment of the limits within which the legislator may restrict the exercise of fundamental rights and freedoms.

At the same time, it should be noted that to a considerable extent, the reasoning of the Constitutional Court is based on that of the European courts, even without explicitly referring to their decisions, the Court is approaching a similar perspective in setting the limits of restrictions on rights and constitutional freedoms from the perspective of national security.

51 See C. Bîrsan, op. cit., p. 248 and S. Peers, op. cit., pp. 393-394.

52 See ECtHR, decision of November $15^{\text {th }}, 1996$, the case of Chahal v. United Kingdom, para. 80 and 151;

${ }^{53}$ ECtHR, the decision of December $13^{\text {th }}, 2012$, the case of El Masri v. Former Yugoslav Republic of Macedonia, para. 257. 